\title{
Growth and liver enzyme response in growing rats to graded levels of methionine and cystine in fortified-barley diets: Response at constant cystine concentration in the diet
}

\author{
BY T. N. NGWIRA AND R. M. BEAMES \\ Department of Animal Science, University of British Columbia, \\ Vancouver, British Columbia V6T I $W_{5}$, Canada
}

(Received 8 February 1978 - Accepted 28 February 1978)

\begin{abstract}
1. Thirty-six male rats of initial age $27 \mathrm{~d}$ were fed on diets based on barley grain for 3 weeks. Crude protein (nitrogen $\times 6.25$ ) was fixed at $120.0 \mathrm{~g} / \mathrm{kg}$ dry matter (DM) and cystine at $2.0 \mathrm{~g} / \mathrm{kg}$ DM in all diets. The basal diet contained $3.5 \mathrm{~g}$ methionine plus cystine $/ \mathrm{kg}$ DM with $\mathrm{L}$-methionine added in increments of $0.5 \mathrm{~g} / \mathrm{kg} \mathrm{DM}$ up to a final level of $7.0 \mathrm{~g}$ methionine plus cystine $/ \mathrm{kg}$ DM. A 'positive control' diet of barley plus $193.7 \mathrm{~g}$ soya-bean meal $/ \mathrm{kg}$ DM contained $6 . \mathrm{g}$ methionine plus cystine/ $\mathrm{kg}$ DM.

2. Weight gain, food conversion efficiency (FCE), urinary urea-N excretion, carcass composition and activities of liver cystathionine synthase $(E C 4.2 .1 .22)$ and $N^{5}$-methyltetrahydrofolate-homocysteinemethyltransferase ( $E C$ 2. I. I. I 3) were determined.

3. Weight gain, FCE and urinary urea-N excretion indicated that levels of 3.5 and $4.0 \mathrm{~g}$ methionine plus cystine $/ \mathrm{kg} \mathrm{DM}$ were inadequate for optimal growth of the rats. These variables indicated $4 \cdot 7 \mathrm{~g} / \mathrm{kg}$ DM to be the requirement for methionine plus cystine. Carcass composition results gave no clear indication of optimal requirements for methionine plus cystine.

4. Cystathionine synthase and $N^{5}$-methyltetrahydrofolate-homocysteine-methyltransferase activities $(/ \mathrm{mg}$ protein per $60 \mathrm{~min}$ ) were constant at $24.32 \mu \mathrm{mol}$ and $0.64 \mathrm{nmol}$ respectively, when methionine plus cystine level was between 3.5 and $5.0 \mathrm{~g} / \mathrm{kg}$ DM. Cystathionine synthase was then inhibited at the $6.0 \mathrm{~g} / \mathrm{kg} \mathrm{DM} \mathrm{level} \mathrm{to}$ a minimum activity of $16.12 \mu \mathrm{mol} / \mathrm{mg}$ protein per $60 \mathrm{~min}$, whereas activity of the re-methylation enzyme increased to a maximum level of $2.92 \mathrm{nmol} / \mathrm{mg}$ protein per $60 \mathrm{~min}$ at the $6.0 \mathrm{~g} / \mathrm{kg}$ DM level of methionine plus cystine. At the levels of methionine plus cystine above $6.0 \mathrm{~g} / \mathrm{kg}$ DM cystathionine synthase activity increased while the activity of $N^{5}$-methyltetrahydrofolate-homocysteine-methyltransferase decreased.
\end{abstract}

Most published estimates of the methionine plus cystine requirements of the growing rat and the growing pig have been based on either growth and nitrogen balance results (Byington, Howe \& Clark, 1972; Sowers, Stockland \& Meade, 1972; Braude \& Esnaola, 1973; Stockland, Meade, Wass \& Sowers, 1973; Brown \& Cline, 1974) or serum and plasma amino acid levels (Byington \& Howe, 1972; Keith, Christensen \& Owen, I972; Knipfel, Owen \& Christensen, 1972; Keith, Peace, Botting \& Hamilton, 1975). There has been very little research (Benevenga, 1974; Finkelstein, 1974) into whether enzymes associated with the methionine metabolic pathway could be utilized in assessing the optimal requirements for methionine plus cystine.

The trans-sulphuration and re-methylation pathways have been shown by Finkelstein (1974) to share the common intermediate, homocysteine. After homocysteine is formed it can be converted to either cystathionine by cystathionine synthase $(E C 4.2 .1 .22)$ or back to methionine by two enzymes, betaine-homocysteine-methyltransferase (EC 2.I.I.5) and $N^{5}$-methyltetrahydrofolate-homocysteine-methyltransferase ( $E C$ 2.I.I.I3). The reaction producing cystathionine has been shown (Finkelstein, I962) to be the only channel leading to irreversible transformation of methionine to other sulphur compounds or body protein in the form of cystine. Finkelstein (I962) showed that cystathionine synthase activity decreased when rats were fed on low-protein diets and increased when they were fed on high-protein diets, but in neither instance was the dietary level of methionine plus cystine stated. 
Table I. Composition ( $\mathrm{g} / \mathrm{kg}$ dry matter (DM)) of diets with a constant cystine content of $2 \cdot 0 \mathrm{~g} / \mathrm{kg} \mathrm{DM}$, fed to rats

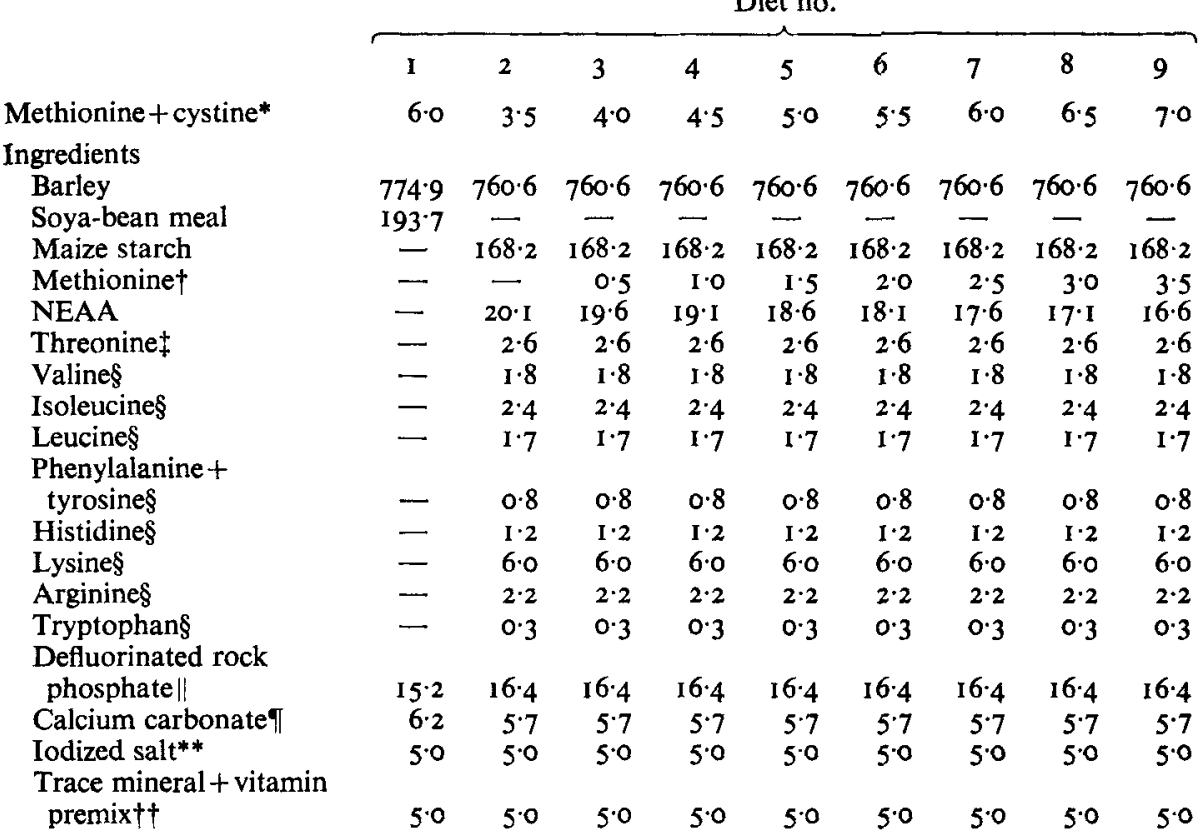

NEAA, Non-essential amino acids were incorporated as a $I: I: I: 1$ mixture of alanine-aspartic acidglycine-glutamic acid (Abernathy \& Miller, I965; Womack, 1969) to bring the crude protein (nitrogen $\times 6 \cdot 25$ ) level to $120.0 \mathrm{~g} / \mathrm{kg}$ dry diet.

* Expressed as total amino acids, not residues.

$\dagger$ Methionine was supplied as L-methionine (Ajinomoto Co., Tokyo, Japan).

$\ddagger$ Incorporated according to Aw-Yong \& Beames (I975).

$\S$ All amino acids were incorporated as L-isomers (Ajinomoto Co.) to meet the (US) National Research Council (1972) recommendations.

|| Estimated to contain $300 \mathrm{~g}$ calcium $/ \mathrm{kg}$ and $\mathrm{I} 40 \mathrm{~g}$ phosphorus $/ \mathrm{kg}$.

T Estimated to contain $400 \mathrm{~g} \mathrm{Ca} / \mathrm{kg}$ and $\circ \mathrm{g} \mathrm{P} / \mathrm{kg}$.

** Estimated to provide $0.15 \mathrm{mg}$ iodine $/ \mathrm{kg}$ dry diet.

$\dagger \dagger$ Provided (/kg dry diet): $44 \mathrm{mg}$ manganese as $\mathrm{MnSO}_{4} \cdot \mathrm{H}_{2} \mathrm{O}$, $110 \mathrm{mg}$ zinc as $\mathrm{ZnSO}_{4} \cdot 7 \mathrm{H}_{2} \mathrm{O}, 500 \mathrm{mg}$ butylated hydroxytoluene, $20 \mu \mathrm{g}$ cyanocobalamin, $2.9 \mathrm{mg}$ ribofiavin, II $\mathrm{mg}$ nicotinic acid, $5 \mathrm{mg}$ calcium pantothenate, $3.6 \mathrm{mg}$ pyridoxine, $0.2 \mathrm{mg}$ D-biotin, $925 \mu \mathrm{g}$ retinol, $10 \mu \mathrm{g}$ ergocalciferol, I g choline chloride.

Methionine can be conserved through the re-methylation reactions when diets are low in either methionine or methionine plus cystine (Finkelstein, 1962; Finkelstein, Kyle \& Harris, I97I, 1974). Finkelstein et al. (1971, I974) indicated that during the re-methylation process, $N^{5}$-methyltetrahydrofolate-homocysteine-methyltransferase is a more important enzyme than the betaine-homocysteine-methyltransferase when methionine is low in the diet. However, when methionine is in excess, the betaine-homocysteine-methyltransferase may become dominant in order to counteract methionine toxicity (Benevenga, 1974), because of the requirement for three molecules of methionine for the formation of each molecule of choline. The choline can then be utilized in the re-synthesis of methionine.

The present experiments were designed to determine whether information obtained from the activities of cystathionine synthase and $N^{5}$-methyltetrahydrofolate-homocysteinemethyltransferase could be used to establish the optimal requirements of methionine plus cysteine for the growing rat, and to compare such estimates with those based on growth, 
Table 2. Amino acid, ${ }^{*}$ protein and gross energy content (/kg dry matter) of barley, soya-bean meal, 'positive-control' diet and basal diet $\dagger$

\begin{tabular}{|c|c|c|c|c|}
\hline & Barley & $\begin{array}{l}\text { Soya-bean } \\
\text { meal }\end{array}$ & $\begin{array}{l}\text { 'Positive- } \\
\text { control' diet }\end{array}$ & Basal diet \\
\hline \multicolumn{5}{|l|}{ Amino acid } \\
\hline Arginine & $5 \cdot \mathrm{I}$ & $29 \cdot 3$ & $9 \cdot 7$ & $6 \cdot 0$ \\
\hline Histidine & $2 \cdot 4$ & $12 \cdot 2$ & 43 & $3 \cdot 0$ \\
\hline Isoleucine & $4 \cdot I$ & $20 \cdot 7$ & $7 \cdot 2$ & 5.5 \\
\hline Leucine & $7 \cdot 7$ & $34 \cdot 6$ & $12 \cdot 7$ & $7 \cdot 5$ \\
\hline Lysine & $4 \cdot 0$ & 28.7 & $9 \cdot 0$ & $9 \cdot 0$ \\
\hline Methionine & $1 \cdot 9$ & $5 \cdot 5$ & $2 \cdot 7$ & I. 5 \\
\hline Cystine & $2 \cdot 7$ & 7.0 & $3 \cdot 3$ & $2 \cdot 0$ \\
\hline Phenylalanine & $6 \cdot 2$ & $22 \cdot 6$ & $9 \cdot 1$ & $5 \cdot 2$ \\
\hline Tyrosine & $3: 3$ & 13.0 & $5 \cdot 2$ & $2 \cdot 8$ \\
\hline Threonine & $4 \cdot I$ & 18.6 & $6 \cdot 9$ & $5 \cdot 7$ \\
\hline Tryptophan & $I \cdot 9$ & $7 \cdot 7$ & $2 \cdot 9$ & $I \cdot 7$ \\
\hline Valine & $5 \cdot 3$ & $2 \mathrm{I} \cdot \mathrm{I}$ & $8 \cdot 2$ & $6 \cdot 8$ \\
\hline Crude protein $(\mathrm{g})$ (nitrogen $\times 6.25$ ) & $106 \cdot 5$ & $484 \cdot 6$ & $171 \cdot 0$ & $120 \cdot 0$ \\
\hline Gross energy $(\mathrm{MJ})$ & $15 \cdot 8$ & $16 \cdot 0$ & 15.9 & I5.8 \\
\hline
\end{tabular}

* Concentrations expressed as total amino acids, not residues.

$\dagger$ For details of diets, see p. 445 and Table $\mathbf{I}$.

urea- $\mathrm{N}$ excretion and published serum and plasma amino acid responses. The diets used in these trials were based on barley grain supplemented with amino acid mixtures varying in methionine content. A 'positive control' diet of barley and soya-bean meal was incorporated in the design.

\section{MATERIALS AND METHODS}

\section{Animals and diets}

Thirty-six male (Woodlyn/Wistar strain, Woodlyn Laboratories, Guelph, Ontario) rats, $27 \mathrm{~d}$ of age at the commencement of the $21 \mathrm{~d}$ feeding period, were used. The rats were randomly assigned to stainless-steel cages with wire-screen floors of $12 \mathrm{~mm}$ spacing. Twelve of the cages were equipped with collection funnels while the others were fitted with trays covered with paper towels beneath the wire screen. The rats were randomly allocated to the urine-collecting cages and urine was collected from each rat for a total period of $4 \mathrm{~d}$, with collection starting on the seventh day of the trial. Each rat was weighed daily throughout the trial.

The diets (Table I) were based on barley grain which was ground in a $200 \mathrm{~mm}$ laboratory hammer mill (Christy and Norris Ltd, Chelmsford, England) fitted with a $0.75 \mathrm{~mm}$ screen. Diets included a 'positive control' (diet I) of barley plus soya-bean meal, plus eight diets of barley plus amino acids, with varying levels of methionine. The basal diet provided (/kg dry matter (DM)) $2.0 \mathrm{~g}$ cystine and $\mathrm{I} \cdot 5 \mathrm{~g}$ methionine. Cystine content was held constant in all eight amino acid-supplemented diets with methionine increments of $0.5 \mathrm{~g} / \mathrm{kg}$ added to a maximum level of $7.0 \mathrm{~g}$ methionine plus cystine $/ \mathrm{kg} \mathrm{DM}$ in diet 9 . The diets were isonitrogenous with $120 \mathrm{~g}$ crude protein $(\mathrm{N} \times 6.25) / \mathrm{kg} \mathrm{DM}$ and isoenergetic with $15.80 \mathrm{MJ}$ gross energy $/ \mathrm{kg}$ DM. Threonine inclusion was based on net requirements estimated by Aw-Yong \& Beames (1975). The requirements for all other nutrients were based on (US) National Research Council (1972) recommended values for the growing rat. Amino acids were added as the L-isomers (Ajinomoto Co., Tokyo, Japan) to meet these requirements. Table 2 shows the amino acid composition of the diets and of the dietary components.

Food was provided ad lib. The water was renewed daily. Body-weights and food intakes were recorded daily. At the conclusion of the $2 \mathrm{I} d$ feeding period, the rats were fasted for 
$18 \mathrm{~h}$. Each rat was then stunned by a blow on the head, the liver rapidly removed, and a portion subjected immediately to each of the two enzyme-extraction methods. After flushing the intestinal tract with water to remove food particles and faecal materials, the carcasses were stored at $-40^{\circ}$ until required for carcass analysis.

\section{Analytical methods}

Cystathionine synthase was extracted from the liver using the method of Kashiwamata \& Greenberg (1970). After precipitation with ammonium sulphate $(307.7 \mathrm{~g} / 1)$, the enzyme was dialysed against $0 . \mathrm{I} \mathrm{M}$-potassium phosphate buffer, $\mathrm{pH} 7 \cdot 5$, and the resulting solution used for the enzyme assay. The protein content of the enzyme extract was determined by the Biuret Method (Wootton, 1974). The assay medium incorporated copper sulphate to inhibit cystathionase. Enzyme activity was monitored by determining the absorption of the product of cystathionine and ninhydrin at $455 \mathrm{~nm}$ (Stasar; Gilford Instrument Laboratories Inc., Oberlin, Ohio, USA). The enzyme activity was expressed as $\mu \mathrm{mol}$ cystathionine formed $/ \mathrm{mg}$ protein per $60 \mathrm{~min}$.

$N^{5}$-methyltetrahydrofolate-homocysteine-methyltransferase was extracted from the livers by the method of Mudd, Levy \& Morrow (1970). After centrifuging at $50000 \mathrm{~g}$ for $\mathrm{I} 20 \mathrm{~min}$, the supernatant fraction was dialysed for $3 \mathrm{~h}$ against three changes of $0 . \mathrm{I}$ M-potassium phosphate buffer, $\mathrm{pH} 7 \cdot 5$, containing $0.003 \mathrm{M}$-reduced glutathione.

The assay medium contained $5-\left[{ }^{14} \mathrm{C}\right]$ methyltetrahydrofolic acid (Amersham Corp., Oakville, Ontario). After paper chromatography in $n$-butyl alcohol-ammonia-water (75:5:20, by vol.; upper phase), the areas positive to ninhydrin were removed, solubilized and counted in PCS liquid-counting cocktail (Amersham Corp.) using a liquid-scintillation counter (Isocap 300; Nuclear-Chicago). The protein content of the enzyme extract was determined by the Biuret Method (Wootton, 1974). Enzyme activity was expressed as nmol methionine formed $/ \mathrm{mg}$ protein per $60 \mathrm{~min}$.

Urinary urea-N was determined using the method by Brown (I97I). Results were expressed as $\mathrm{g} \mathrm{N} / \mathrm{kg}$ dietary DM consumed.

Body composition of the rats was determined after drying the thawed carcasses at $95^{\circ}$ for $72 \mathrm{~h}$. The dried carcasses were weighed and extracted with light petroleum (b.p. $30-60^{\circ}$ ) in a Soxhlet apparatus using $43 \times 123 \mathrm{~mm}$ thimbles (Association of Official Agricultural Chemists, 1975). The residue was dried in an oven, weighed and ground using a $200 \mathrm{~mm}$ laboratory hammer mill using a $0.75 \mathrm{~mm}$ screen. The resulting samples were 'ball-milled' for $24 \mathrm{~h}$ and the uniform powder was used in the analyses of crude protein and ash.

Food and carcass crude protein were determined by the macro-Kjeldahl method, while ash was analysed by dry ashing in a muffle furnace at $550^{\circ}$ (Association of Official Agricultural Chemists, 1975). Gross energy contents of dietary components and diets were determined using an adiabatic bomb calorimeter (A. Gallenkamp and Co. Ltd, London, England).

Amino acid analysis was done on both the barley and soya-bean meal, with hydrolysates prepared by the method of Kohler \& Palter (1967). Cystine was determined as cysteic acid and methionine was determined as methionine sulphone after oxidative hydrolysis with performic acid (Moore, 1963). The samples were analysed using an amino acid analyser (Durrum Model D 500; Durrum, Palo Alto, California, USA). Tryptophan was determined after alkaline-hydrolysis by the method of Hugli \& Moore (1972) using a Beckman-Spinco Analyzer (Model I 20 B; Beckman Instruments Inc., Palo Alto, California, USA).

\section{Statistical procedures}

All results were subjected to analysis of variance and orthogonal contrast as outlined in the University of British Columbia program BMD: IOV (Bjerring, Greig \& Halm, 1975). All 
differences between means were tested at $P<0.05$, using the Newman-Keul's multiple range test according to the program of Bjerring et al. (1975).

\section{RESULTS}

Growth, food intake and food conversion efficiency (FCE) results are presented in Table 3 and carcass results in Table 4.

\section{Average daily body-weight gain}

The average body-weight of the rats at the start of the trial was $100 \cdot 30 \pm \mathrm{I} \cdot 02 \mathrm{~g}$ with no significant difference between treatment groups. At the end of the first week, average daily body-weight gain on the 'positive-control' diet was significantly higher $(P<0.05)$ than on diets 2-9. The daily weight gain on diets 2 and 3 was significantly lower $(P<0.05)$ than on diet $\mathrm{I}$. The gain on diet 3 was not significantly different from gain on diet 4 . However, gain on diets 3 and 4 was significantly lower $(P<0.05)$ than gain on diets $5-9$. The re was no significant difference between diets 4 and 5 .

For the second week, orthogonal contrasts (Table 5) indicated that $4.0 \mathrm{~g}$ methionine plus cystine $/ \mathrm{kg}$ diet met requirements, whereas $4.5 \mathrm{~g} / \mathrm{kg}$ diet was required for maximal growth in the third week. For the over-all period, $4.0 \mathrm{~g} / \mathrm{kg}$ diet again appeared adequate.

\section{Average daily food intake}

There was no significant difference between treatments in the amount of food consumed during each of the first 2 weeks as well as during the over-all trial period. However, food intake on the 'positive-control' diet during the third week was significantly higher $(P<0.05)$ than on diets 2 and 3, whereas other contrasts gave no significant differences.

\section{Average FCE}

During the first week of the trial, FCE of rats on the 'positive-control' diet was significantly higher $(P<0.05)$ than on diets $2-9$ as well as on diets $4-9$. FCE on diets 2 and 3 was significantly lower $(P<0.05)$ than on diets $4-9$. Although differences between diet 3 and diet 4 and between diet 4 and diet 5 were not significant, the difference between diets 3 and 4 and diets 5-9 was significant. These differences persisted in the second week, although performance on diet 2 improved, to equal that on diet 3 .

During the third week, diets 2 and 3 gave an FCE that was significantly lower $(P<0.05)$ than that obtained on diets 4-9. All other contrasts yielded no significant differences.

Results of the over-all trial period showed that the FCE on diet 2 was significantly lower $(P<0.05)$ than on diet 3 . The lack of difference between diet 3 and diet 4 , but a greater efficiency on diets 5-9 than on diets 3 and 4 indicated requirements to be between $4.5 \mathrm{~g}$ and $5.0 \mathrm{~g}$ methionine plus cystine $\mathrm{kg}$ diet.

The FCE values are plotted in Fig. I. Values were tested for 'fit' in the equations: $y=a b^{x}$; $y=a+(b / x) ; y=a+b x+c x^{2}$, where $y$ is the FCE (g gain/g food), $x$ is the diet.. methionine plus cystine level $(\mathrm{g} / \mathrm{kg}), a, b, c$ are constants. The following relationships $\mathrm{w}$ developed:

$$
\begin{aligned}
& y=0.1794(1.094)^{x}\left(R^{2} 0.56 ; P<0.05\right) \\
& y=0.4209-(0.6501 / x)\left(R^{2} 0.65 ; P<0.05\right) \\
& y=-0.095+0.1271 x-0.0098 x^{2}\left(R^{2} 0.66 ; P<0.05\right) .
\end{aligned}
$$

The regression curves derived from the latter two equations are presented in Fig. $I$. 


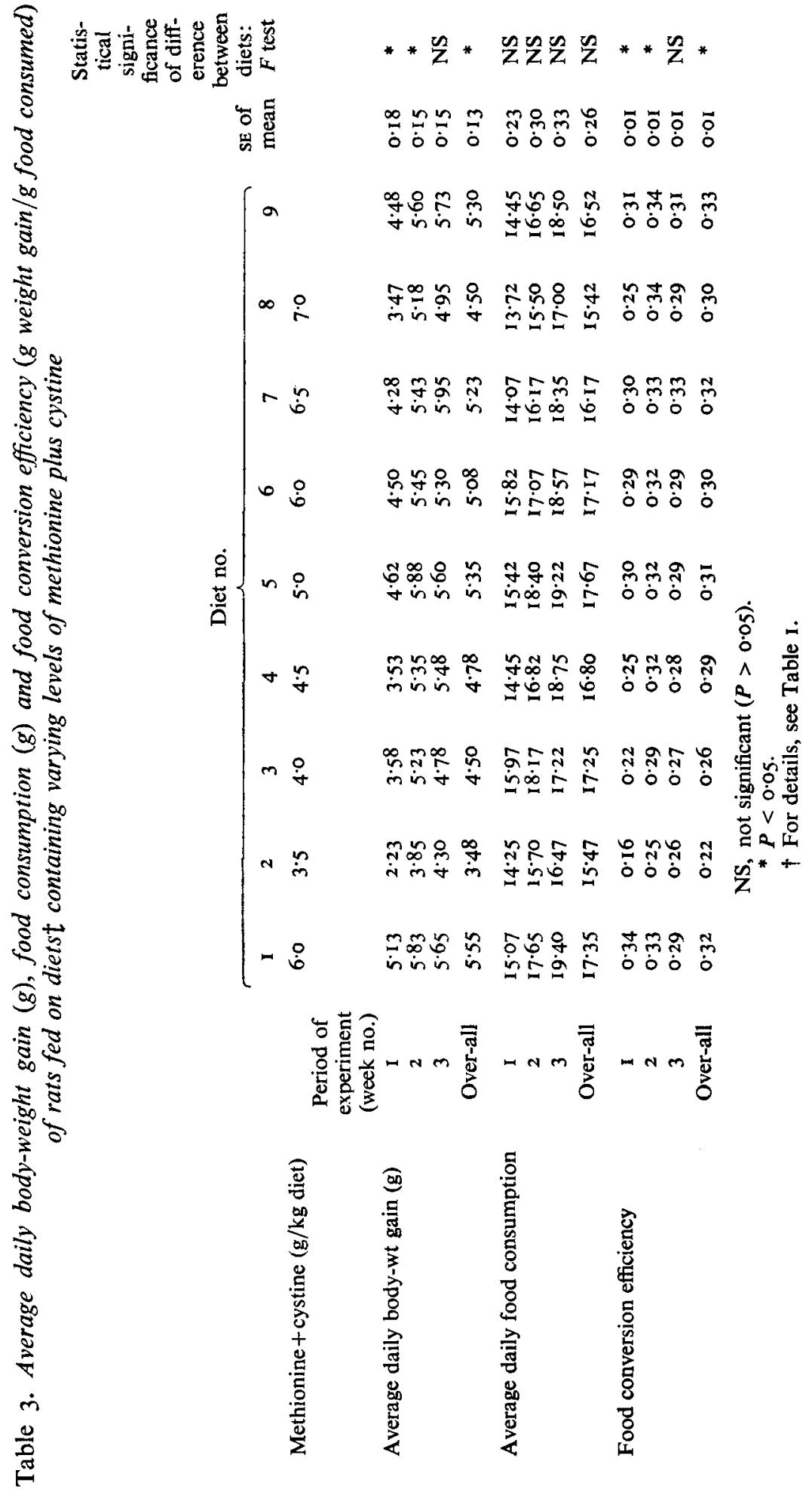




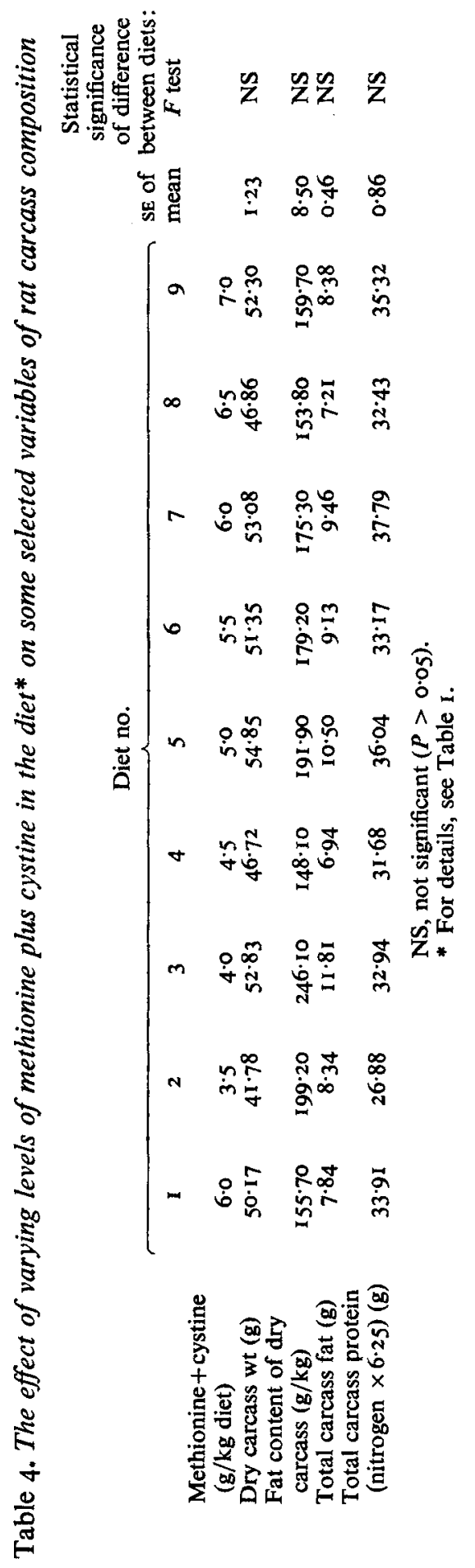


Table 5. Results of orthogonal contrasts of variables presented in Tables 3 and 4

Comparisons of diets nos.:

\begin{tabular}{|c|c|c|c|c|c|c|c|c|c|}
\hline & \multirow[b]{2}{*}{$\begin{array}{l}\text { Period of } \\
\text { experiment } \\
\text { (week no.) }\end{array}$} & & \\
\hline & & $\begin{array}{l}\text { I } v . \\
2-9\end{array}$ & $\begin{array}{c}I v \\
2 \text { and } \\
3\end{array}$ & $\begin{array}{l}1 v . \\
4-9\end{array}$ & $2 v \cdot 3$ & $\begin{array}{c}2 \text { and } 3 \\
\nu . \\
4-9\end{array}$ & 3 v. 4 & $\begin{array}{c}3 \text { and } 4 \\
v_{5}-9\end{array}$ & $4 v .5$ \\
\hline \multirow{4}{*}{$\begin{array}{l}\text { Average daily body-wt } \\
\text { gain }(\mathrm{g})\end{array}$} & I & $*$ & $*$ & $*$ & $*$ & $*$ & NS & $*$ & NS \\
\hline & 2 & NS & $*$ & NS & $*$ & $*$ & NS & NS & NS \\
\hline & 3 & NS & $*$ & NS & NS & $*$ & NS & NS & NS \\
\hline & Over-all & $*$ & $*$ & NS & $*$ & $*$ & NS & NS & NS \\
\hline \multirow{4}{*}{$\begin{array}{l}\text { Average daily food } \\
\text { consumption }(\mathrm{g})\end{array}$} & I & NS & NS & NS & NS & NS & NS & NS & NS \\
\hline & 2 & NS & NS & NS & NS & NS & NS & NS & NS \\
\hline & 3 & NS & $*$ & NS & NS & NS & NS & NS & NS \\
\hline & Over-all & NS & NS & NS & NS & NS & NS & NS & NS \\
\hline \multirow{4}{*}{$\begin{array}{l}\text { Food conversion efficiency } \\
\text { ( } \mathrm{g} \text { wt gain } / \mathrm{g} \text { food } \\
\text { consumed) }\end{array}$} & I & $*$ & $*$ & $*$ & $*$ & $*$ & NS & $*$ & NS \\
\hline & 2 & NS & $*$ & NS & NS & $*$ & NS & $*$ & NS \\
\hline & 3 & NS & NS & NS & NS & $*$ & NS & NS & NS \\
\hline & Over-ail & $*$ & * & NS & $*$ & $*$ & NS & $*$ & NS \\
\hline \multirow{5}{*}{$\begin{array}{l}\text { Dry carcass wt }(\mathrm{g}) \\
\text { Fat concentration of dry } \\
\text { carcass }(\mathrm{g} / \mathrm{kg}) \\
\text { Total carcass fat }(\mathrm{g}) \\
\text { Total carcass crude protein } \\
(\text { nitrogen } \times 6.25)(\mathrm{g})\end{array}$} & & NS & NS & NS & $*$ & NS & NS & NS & NS \\
\hline & & NS & $*$ & NS & NS & * & $*$ & NS & NS \\
\hline & & NS & NS & NS & NS & NS & * & NS & NS \\
\hline & & & & & & & & & \\
\hline & & NS & NS & NS & NS & $*$ & NS & NS & NS \\
\hline
\end{tabular}

\section{Carcass composition}

Variables that showed no significant differences between treatments, both by Newman-Keul's multiple range test and by orthogonal contrasts were: crude protein in fat-free carcass $(\mathrm{g} / \mathrm{kg})$, crude protein in the whole carcass $(\mathrm{g} / \mathrm{kg})$, ash in fat-free carcass $(\mathrm{g} / \mathrm{kg})$, ash in the whole carcass $(\mathrm{g} / \mathrm{kg})$ and total carcass ash.

Rats on diet 2 had a significantly lower $(P<0.05)$ final dry carcass weight than rats on diet 3 . The other contrasts on the final carcass weight showed no significant difference between treatments. The fat content $(\mathrm{g} / \mathrm{kg})$ of the carcass of the 'positive-control' rats was significantly lower $(P<0.05)$ than that in rats on diets 2 and 3 . Carcasses of rats on diets 2 and 3 contained significantly greater $(P<0.05)$ fat concentrations than carcasses of rats on diets $4-9$, while carcasses of rats on diet 3 contained significantly greater $(P<0.05)$ fat concentrations than carcasses of rats on diet 4. Other contrasts on the fat concentration $(\mathrm{g} / \mathrm{kg})$ of the whole carcass showed no significant differences between treatments. Rats on diet 3 had a significantly higher $(P<0.05)$ total carcass fat content than rats on diet 4 ; whereas all other contrasts on the same variable showed no significant differences. The values for total carcass protein indicated rats on diets 2 and 3 to have significantly lower $(P<0.05)$ total carcass protein contents than rats on diets $4-9$.

\section{Urinary urea- $N$ excretion}

Fig. 2, relating dietary methionine plus cystine to urea- $\mathrm{N}$ excretion, shows a sharp decrease from $2.78 \mathrm{~g}$ urea-N $/ \mathrm{kg}$ DM consumed at $3.5 \mathrm{~g}$ methionine plus cystine $/ \mathrm{kg}$ DM to $\mathrm{I} \cdot 40 \mathrm{~g}$ urea-N/ $\mathrm{kg}$ DM consumed at $4.5 \mathrm{~g}$ methionine plus cystine $/ \mathrm{kg}$ DM. The reduction in urinary urea excretion then diminished markedly to a slow linear decrease as the concentration of 


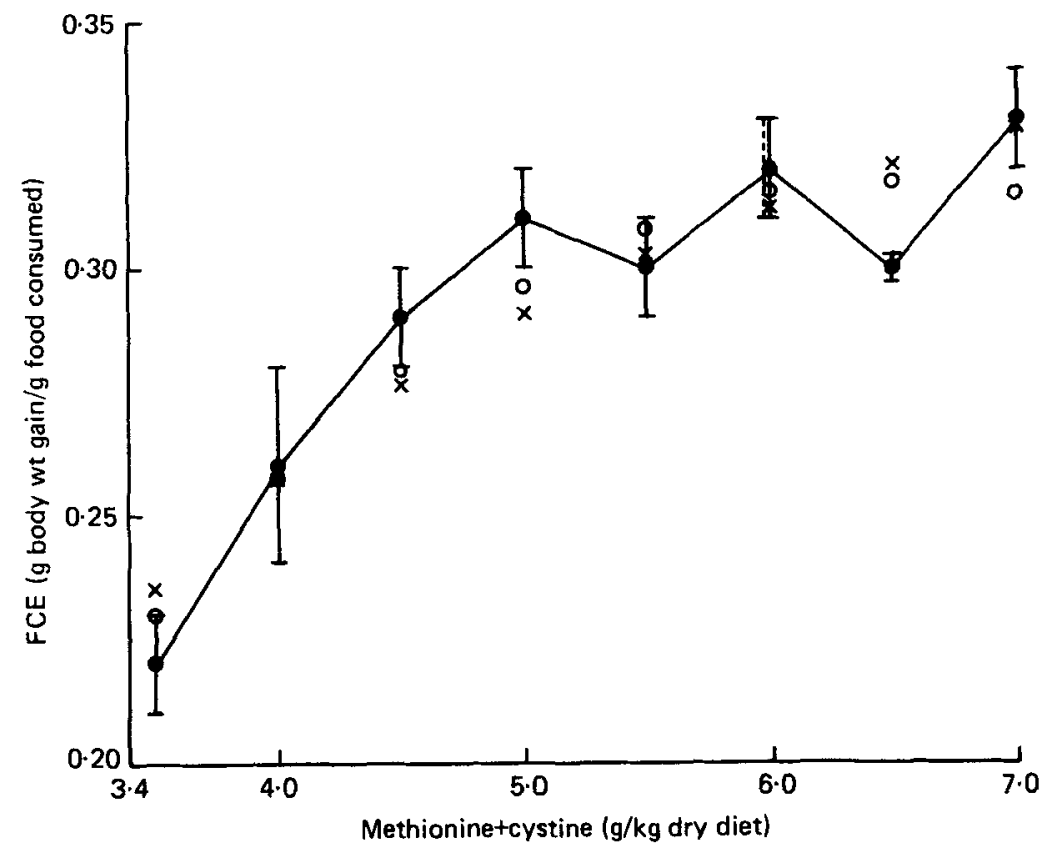

Fig. $\mathrm{r}$. The relationship between dietary methionine plus cystine levels $(\mathrm{g} / \mathrm{kg})$ in diets fed to rats and food conversion efficiency (FCE; $g$ body-weight gain/g food consumed) of the rats from 28 to $49 \mathrm{~d}$ of age. The points represent mean values with their standard errors represented by vertical bars for four rats per dietary treatment. 'Positive control' diet (diet no. I); 0 , experimental values; $x$, experimental values fitted to equation $y=0.4209-(0.650 \mathrm{I} / \chi) ; 0$, experimental values fitted to equation $y=-0.095+0.1271 \chi-0.0098 \chi^{2}$. For details of diets see Table $\mathrm{I}$.

dietary methionine plus cystine increased to the $7.0 \mathrm{~g} / \mathrm{kg}$ DM level. Fig. 2 shows a diminution of the rate of decrease beyond $4.5 \mathrm{~g}$ dietary methionine plus cystine $/ \mathrm{kg}$ DM consumed.

The urinary urea excretion results are plotted in Fig. 2. Values were tested for 'fit' in the equations: $y=a b^{x} ; y=a+b / x ; y=a+b x+c x^{2}$, where $y$ is the urinary urea-N excretion (g/ $\mathrm{kg}$ DM consumed); $x$ is dietary methionine plus cystine level $(\mathrm{g} / \mathrm{kg} \mathrm{DM}), a, b, c$ are constants. The following relationships were developed:

$$
\begin{aligned}
& y=4.087(0.82)^{x}\left(R^{2} 0.77 ; P<0.05\right), \\
& y=-0.3277+(9.149 / x)\left(R^{2} 0.73 ; P<0.05\right), \\
& y=8.174-2.299 x+0.187 x^{2}\left(R^{2} 0.83 ; P<0.05\right) .
\end{aligned}
$$

Although the polynomial curve explained 0.83 of the variance, it deviated considerably from the observed pattern between the levels 6.0 and $7.0 \mathrm{~g}$ dietary methionine plus cystine/ $\mathrm{kg}$ DM. Consequently it was not considered to be of any aid in the interpretation of the results.

\section{Activities of the liver enzymes}

The activity of liver cystathionine synthase (Fig. 3) shows an almost constant level of 24.32 $\mu \mathrm{mol} / \mathrm{mg}$ protein per $60 \mathrm{~min}$ between $3.5 \mathrm{~g}$ and $5^{\circ} 0 \mathrm{~g}$ methionine plus cystine $/ \mathrm{kg}$ DM intake. The activity thereafter decreased, reaching an average minimum of $16.12 \mu \mathrm{mol} / \mathrm{mg}$ protein per $60 \mathrm{~min}$ at the $6.0 \mathrm{~g} / \mathrm{kg}$ level, subsequently increasing to an average level of $23.69 \mu \mathrm{mol} / \mathrm{mg}$ protein per $60 \mathrm{~min}$ at the $7.0 \mathrm{~g} / \mathrm{kg}$ level.

The activity of liver $N^{5}$-methyltetrahydrofolate-homocysteine-methyltransferase (Fig. 4) 


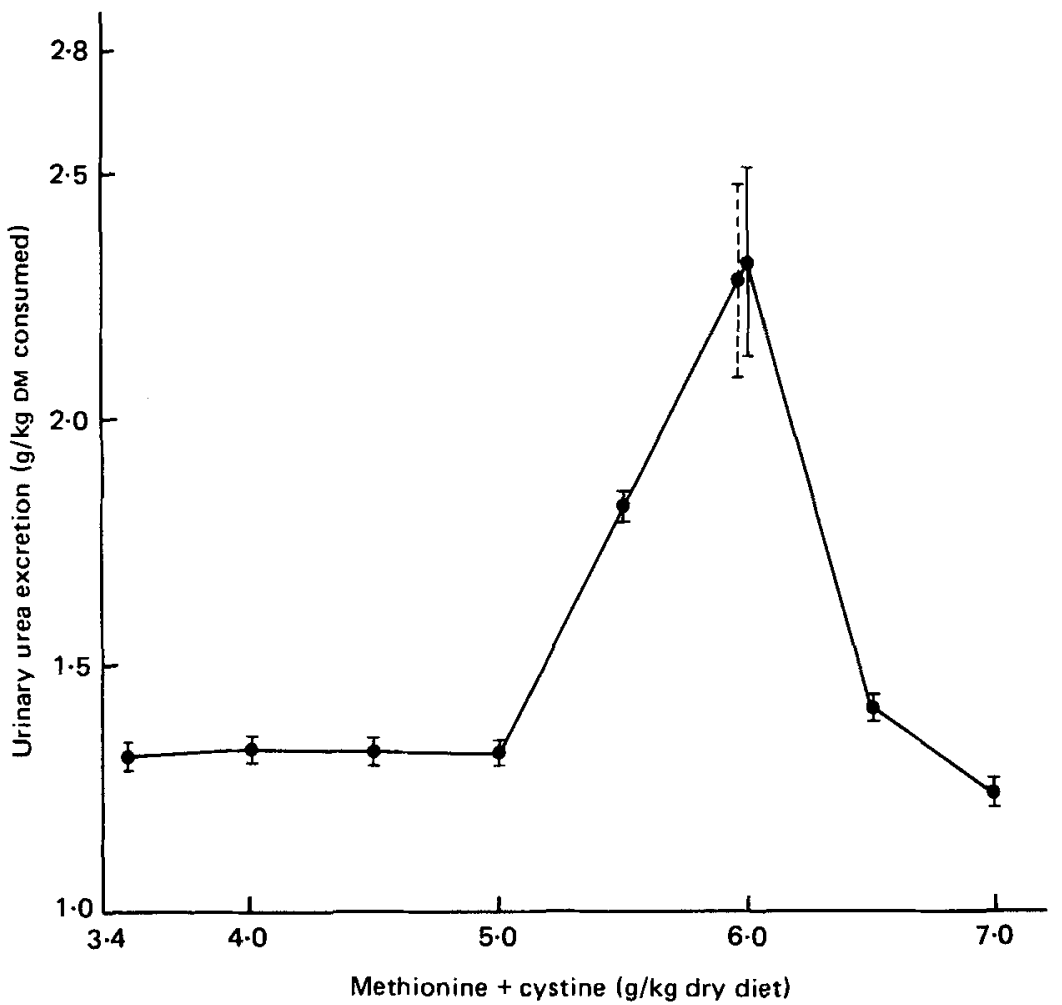

Fig. 2. The relationship between dietary methionine plus cystine levels $(\mathrm{g} / \mathrm{kg})$ and urinary urea excretion ( $\mathrm{g} / \mathrm{kg}$ dry matter (DM) consumed) by rats on diets nos. 2-9 (for details, see Table $\mathrm{I}$ ). Points represent mean values with their standard errors represented by vertical bars for four rats/dietary treatment.

was constant at $0.64 \mathrm{nmol} / \mathrm{mg}$ protein per 60 min between the levels of 3.5 and $5.0 \mathrm{~g}$ methionine plus cystine $/ \mathrm{kg}$ DM intake. It then increased to an average value of $2.92 \mathrm{nmol} / \mathrm{mg}$ protein per $60 \mathrm{~min}$ at the $6.0 \mathrm{~g}$ methionine plus cystine $/ \mathrm{kg} \mathrm{DM}$ intake, thereafter decreasing to $0.48 \mathrm{nmol} / \mathrm{mg}$ protein per $60 \mathrm{~min}$ at the $7.0 \mathrm{~g} / \mathrm{kg} \mathrm{DM}$ level.

\section{DISCUSSION}

During the 3 weeks of the trial, weight gain was poorest on the diets containing 3.5 and $4.0 \mathrm{~g}$ methionine plus cystine $/ \mathrm{kg}$ DM but the higher gains attained on the diets containing 4.5-7.0 $\mathrm{g}$ methionine plus cystine $/ \mathrm{kg}$ DM could not be statistically differentiated from each other or from the 'positive-control' diet. It should be noted that as the rats matured, weight gain on both 3.5 and $4.0 \mathrm{~g}$ dietary methionine plus cystine $/ \mathrm{kg}$ DM more closely approached gains obtained on the other diets, presumably as a result of the rapidly decreasing methionine requirements as the rat ages (Hartsook \& Mitchell, I956).

FCE results indicated that levels of 3.5 and $4.0 \mathrm{~g}$ dietary methionine plus cystine $/ \mathrm{kg} \mathrm{DM}$ were insufficient for optimal growth in the rat. Like the weight-gain results, there was no distinction between diets within the methionine plus cystine range of $4.5-7.0 \mathrm{~g} / \mathrm{kg}$ DM. Fig. I shows a levelling-off in growth rate between 4.5 and $5.0 \mathrm{~g}$ dietary methionine plus cystine $/ \mathrm{kg}$ DM although mean values beyond the $5.0 \mathrm{~g} / \mathrm{kg}$ DM level did not show a consistent pattern. The 'fitting' of the values to reciprocal and polynomial equations only partially $\left(R^{2} 0.65\right.$, $P<0.05 ; R^{2} 0.66, P<0.05$ respectively) explained the variance. The 'fitting' of these 


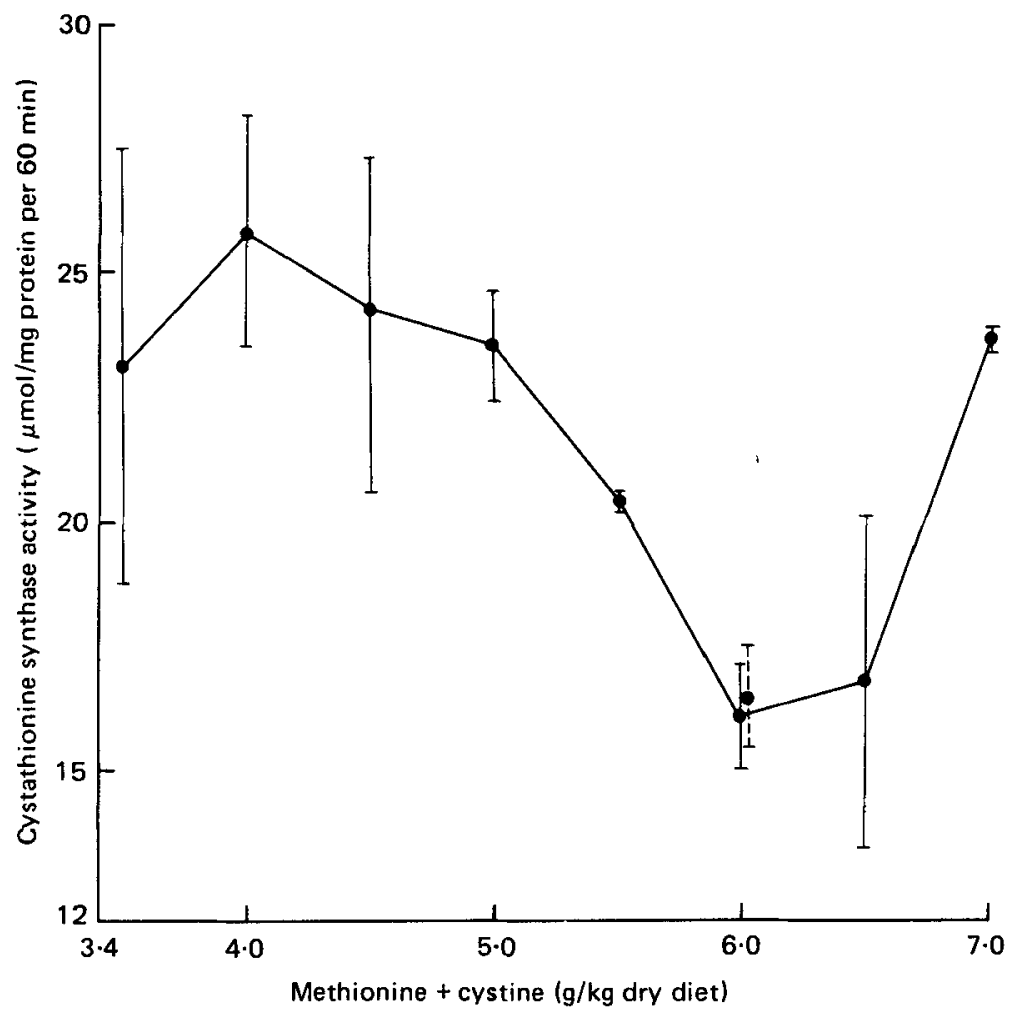

Fig. 3. Response of liver cystathionine synthase $(E C 4.2 .1 .22)$ activity $(\mu \mathrm{mol} / \mathrm{mg}$ protein per $60 \mathrm{~min})$ in rats to varying levels $(\mathrm{g} / \mathrm{kg}$ ) of dietary methionine plus cystine. Points represent mean values with their standard errors represented by vertical bars for four rats/dietary treatment. 'Positive-control' diet (diet no. 1). For details of diets, see Table 1.

curves did little to aid in the interpretation of the results beyond the level of $5.0 \mathrm{~g}$ dietary methionine plus cystine/ $\mathrm{kg}$ DM, where the FCE values presented an erratic pattern. No explanation could be advanced for this pattern. Changes did not coincide with the changes in concentration of liver enzymes. The results could be interpreted to indicate $4.5-5.0 \mathrm{~g}$ methionine plus cystine/ $\mathrm{kg}$ DM to be adequate for the growing rat. This optimal range, when expressed as $33 \cdot 4-36.7 \mathrm{mmol}$ total $\mathrm{S}$ from methionine plus cystine $/ \mathrm{kg}$ DM is in agreement with values reported by Sowers et al. (1972) and by Stockland et al. (1973), but different from the requirements suggested by Womack \& Rose (194I), and by the (US) National Research Council (1972) who both give requirements of $6.7 \mathrm{~g}$ dietary methionine plus cystine $/ \mathrm{kg}$ DM, with cystine able to contribute one-third to half the total $\mathrm{S}$ intake from methionine plus cystine.

Results obtained from carcass analyses clearly indicated that these criteria could not be used in the assessment of methionine plus cystine requirements of the growing rat, especially within the range covered in the present investigation. The few significant differences shown by the orthogonal comparisons in dry carcass weight, carcass fat $(\mathrm{g} / \mathrm{kg})$, total carcass fat and total carcass protein, although giving some support to the weight gain and FCE results, are of limited usefulness as they often appear contradictory. This lack of close correlation is contrary to the findings of Williams, Curtin, Abraham, Loosli \& Maynard (I954), who, using carcass composition as a criterion, estimated the methionine plus cystine requirements for the growing rat to be $4.3 \mathrm{~g} / \mathrm{kg} \mathrm{DM}$, which is close to the range obtained in this trial. 


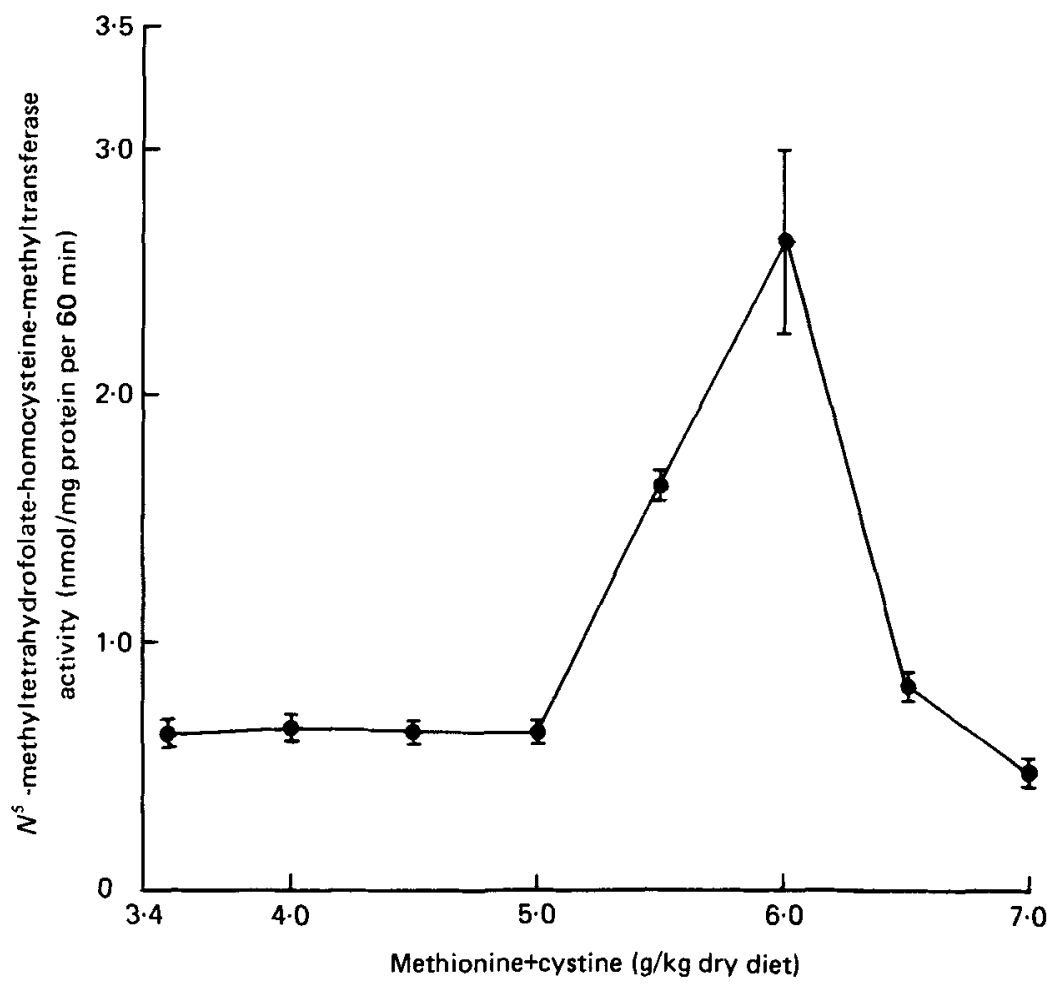

Fig. 4. Response of liver $N^{5}$-methyltetrahydrofolate-homocysteine-methyltransferase activity $(\mathrm{nmol} / \mathrm{mg}$ protein per $60 \mathrm{~min}$ ) in rats to varying levels $(\mathrm{g} / \mathrm{kg}$ ) dietary methionine plus cystine. Points represent mean values with their standard errors represented by vertical bars for four rats per dietary treatment. 'Positive-control' diet (diet no. I). For details of diets, see Table $\mathbf{~}$.

Urinary urea excretion results indicated that the optimal dietary requirement of methionine plus cystine may be $4.5 \mathrm{~g} / \mathrm{kg}$ DM or $33.4 \mathrm{mmol}$ total S from methionine plus cystine $/ \mathrm{kg} \mathrm{DM}$. However, the gradual decrease in urea- $\mathrm{N}$ excretion with $4 \cdot 5-7 \cdot 0 \mathrm{~g}$ methionine plus cystine $/ \mathrm{kg}$ DM indicated a possible continuing improvement in total amino acid utilization. Although these results essentially are in agreement with those of FCE, whereby $4.5 \mathrm{~g}$ methionine plus cystine/ $\mathrm{kg}$ DM was the point where maximum change in response occurred, the urinary urea excretion curve was a less variable indicator beyond this level. Other workers (Brown \& Cline, 1974; Fuller, Livingstone \& Mennie, 1975) also have found urinary urea excretion to be a sensitive criterion for the assessment of amino acid requirements.

Results obtained with the enzymes indicated that normal enzyme activity was disturbed when dietary methionine plus cystine was increased beyond the $5.0 \mathrm{~g} / \mathrm{kg}$ DM level. Cystathionine synthase activity inhibition started at $5.0 \mathrm{~g} / \mathrm{kg}$ DM and reached a maximum at $6.0 \mathrm{~g}$ dietary methionine plus cystine $/ \mathrm{kg}$ DM. This inhibition could have arisen from the accumulation of methionine, $N, N$-dimethyl glycine and possibly $S$-adenosyl-methionine, the immediate products of the re-methylation reactions (Fig. 5), or by cystathionine, the end-product of the enzyme reaction. Accumulation of $S$-adenosyl-homocysteine (SAH) would not be likely to cause inhibitions, since Finkelstein et al. (1974) showed that SAH-activated cystathionine synthase at all concentrations of substrate serine and homocysteine. One other possible factor which may have inhibited the activity of cystathionine synthase was methionine: cystine, which was shown by Shannon, Howe \& Clark (1972) to affect the activity of this enzyme. Shannon 


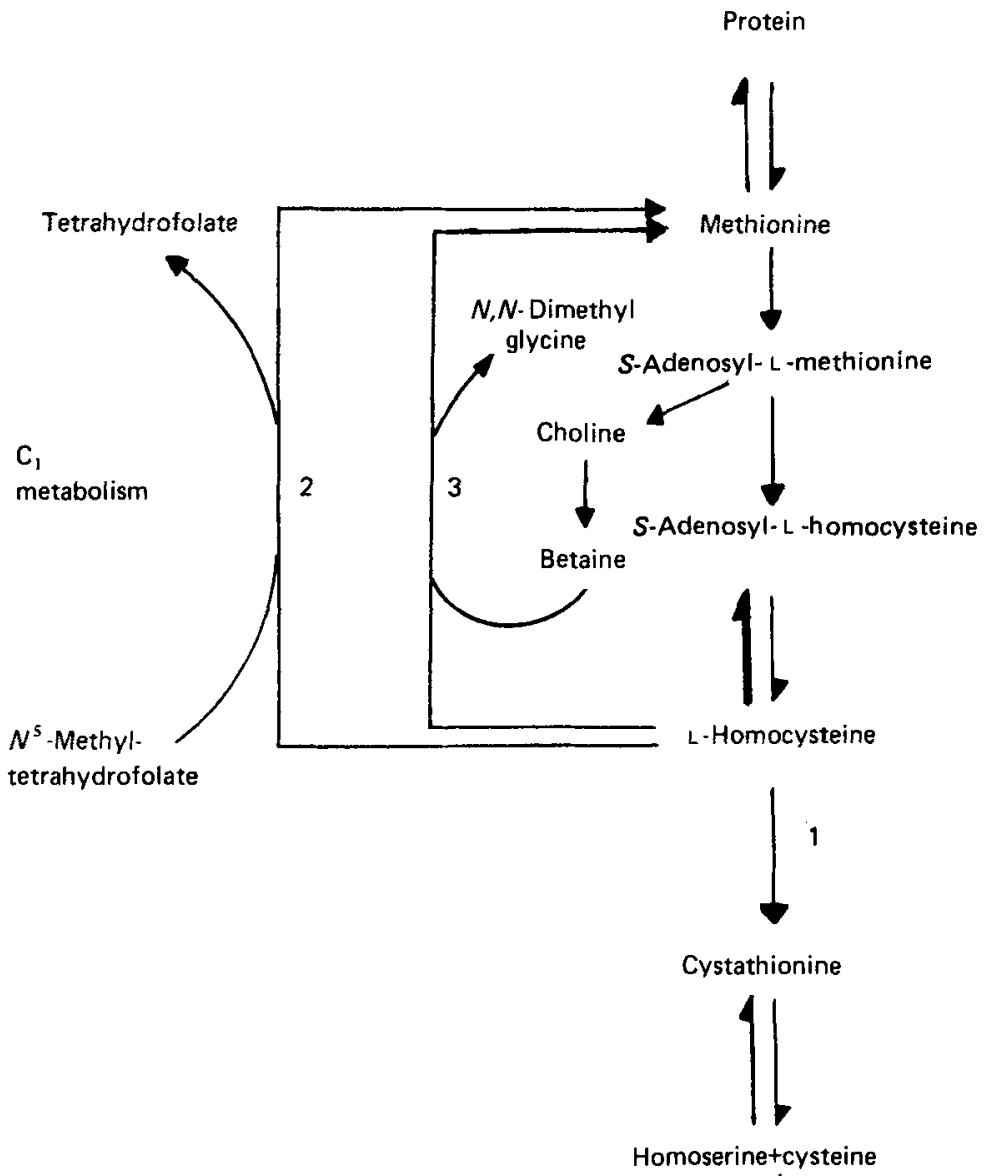

Fig. 5. Diagrammatic scheme for the methionine metabolic pathway. I, Catalysed by cystathionine synthase (EC 4.2.1.22);2, catalysed by $N^{5}$-methyltetrabydrofolate-homocysteine-methyltransferase ( $E C$ 2.I.I.13);3, catalysed by betaine-homocysteine-methyltransferase ( $E C$ 2.I.I.5).

et al. (1972) observed maximum inhibition of the enzyme at a point where cystine accounted for $50 \%$ or more of the total S amino acids in the diets, whereas in the present trial maximum inhibition was at a point where cystine accounted for $33 \%$ of the total S amino acids. However, in this trial, methionine:cystine was confounded with total level of inclusion of these two amino acids. An experiment to investigate the effect of total methionine plus cystine, independent of methionine:cystine, will be reported in a subsequent paper. The present trial also showed a definite increase in the activity of cystathionine synthase as the dietary level of methionine plus cystine increased from $6 \cdot 0$ to $7 \cdot 0 \mathrm{~g} / \mathrm{kg} \mathrm{DM}$. It was not likely that this was due to activation by serine since dietary serine content was the same in all the experimental diets. However, this increased enzyme activity could have been partly as a result of an increase in the products of re-methylation.

As cystathionine synthase activity was being inhibited, $N^{5}$-methyltetrahydrofolatehomocysteine-methyltransferase activity was increasing, both activities being simultaneously affected at $5^{\circ} \mathrm{O} \mathrm{g}$ dietary methionine plus cystine $/ \mathrm{kg}$ DM. The former reached its minimum activity while the latter reached its maximum activity at the level of $6.0 \mathrm{~g}$ dietary methionine plus cystine/kg DM. From these observations it may be suggested that whatever product inhibited cystathionine synthase activity must have activated the re-methylation process via 
the reaction catalysed by $N^{5}$-methyltetrahydrofolate-homocysteine-methyltransferase. When the dietary level of methionine plus cystine increased from 6.0 to $7.0 \mathrm{~g} / \mathrm{kg} \mathrm{DM}$, the activity of the re-methylation enzyme decreased, in agreement with observations by Finkelstein et al. (I97I). This inhibition probably may be due to product inhibition as suggested by Burke, Mangum \& Brodie (197I).

In summary, results from weight gain and FCE indicate $45^{-5} 5^{\circ} \mathrm{g}$ dietary methionine plus cystine $/ \mathrm{kg}$ DM to be the optimal range for growth of weanling rats. The same variables show that 3.5 and $4.0 \mathrm{~g}$ dietary methionine plus cystine $/ \mathrm{kg} \mathrm{DM}$ are unable to support optimal growth in young rats. Urinary urea excretion results indicate that $4 \cdot 2-4 \cdot 7 \mathrm{~g}$ dietary methionine plus cystine $/ \mathrm{kg}$ DM is an optimal range for growth in young rats, although maximal utilization of the added methionine was still improving slowly, even at $7.0 \mathrm{~g} / \mathrm{kg} \mathrm{DM}$. Enzyme activities indicated that there is normal metabolism at $3.5-5.0 \mathrm{~g}$ dietary methionine plus cystine $/ \mathrm{kg}$ DM and that levels beyond $5.0 \mathrm{~g} / \mathrm{kg}$ DM result in disturbances in enzyme activities. This, therefore, means that efforts to define more accurately total $\mathrm{S}$ amino acid requirements for growing rats should be concentrated within the range $4^{\circ} 0-5^{\circ} \circ \mathrm{g}$ dietary methionine plus cystine $/ \mathrm{kg} \mathrm{DM}$ when dietary methionine is of the order of $2.0 \mathrm{~g} / \mathrm{kg}$ DM. The (US) National Research Council (1972) value of $6.7 \mathrm{~g} / \mathrm{kg}$ DM for methionine plus cystine is, according to the present results, rather high and at the level of maximum enzyme disturbance.

The authors thank the National Research Council of Canada and the Canadian Commonwealth Scholarship and Fellowship Committee for supporting this work, and M. Striker for statistical assistance.

\section{REFERENCES}

Abernathy, R. P. \& Miller, J. (1965). J. Nutr. 86, 231.

Association of Official Agricultural (Chemists 1975). Official Methods of Analysis, I I th ed. Washington, DC: Association of Official Agricultural Chemists.

Aw-Yong, L. M. \& Beames, R. M. (1975). Can. J. Anim. Sci. 55, 765.

Benevenga, N. J. (1974). J. agric. Fd Chem. 22, 2.

Bjerring, J. H., Greig, M. \& Halm, J. (1975). U.B.C. BMD IoV. Vancouver, British Columbia: Computing Centre of University of British Columbia, Vancouver.

Braude, R. \& Esnaola, M. A. (1973). Br. J. Nutr. 30, 437.

Brown, J. A. \& Cline, T. R. (1974). J. Nutr. 104, 542.

Brown, J. F. (1971). Am. J. med. Technol. 37, I84.

Burke, G. T., Mangum, J. H. \& Brodie, J. D. (1971). Biochemistry, Easton 10, 3079.

Byington, M. H. \& Howe, J. M. (1972). J. Nutr. 102, 995.

Byington, M. H., Howe, J. M. \& Clark, H. E. (1972). J. Nutr. 102, 219.

Finkelstein, J. D. (1962). Archs Biochem. Biophys. 122, 583.

Finkelstein, J. D. (1972). Archs Biochem. Biophys. 153, 320.

Finkelstein, J. D. (1974). Metabolism 23, 387.

Finkelstein, J. D., Kyle, W. E. \& Harris, B. J. (197I), Archs Biochem. Biophys. 146, 84.

Finkelstein, J. D., Kyle, W. E. \& Harris, B. J. (1974). Archs Biochem. Biophys. 165, 774.

Fuller, M. F., Livingstone, R. M. \& Mennie, I. (1975). Proc. Nutr. Soc. 34, 99 A.

Hartsook, E. W. \& Mitchell, H. H. (1956). J. Nutr. 6o, 173.

Hugli, T. E. \& Moore, S. (1972). J. biol. Chem. 237, 2828.

Kashiwamata, S. \& Greenberg, D. M. (1970). Biochim. biophys. Acta 212, 488.

Keith, M. O., Christensen, D. A. \& Owen, B. D. (1972). Can. J. Anim. Sci. 52, 163.

Keith, M. O., Peace, R. W., Botting, H. G. \& Hamilton, E. J. (1975). J. Nutr. ro5, 1535.

Knipfel, J. E., Owen, B. D. \& Christensen, D. A. (1972). Can. J. Anim. Sci. 52, I55.

Kohler, G. O. \& Palter, R. (1967). Cereal Chem. 44, 512.

Moore, S. (1963). J. biol. Chem. 238, 235.

Mudd, S. H., Levy, H. L. \& Morrow, G. (1970). Biochem. Med. 4, 193.

National Research Council (1972). Nutrient Requirements of Domestic Animals, no. 10. Nutrient Requirements of Laboratory Animals, 2nd revised ed. Washington, DC: National Research Council.

Shannon, B. M., Howe, J. M. \& Clark, H. E. (1972). J. Nutr. 102, 557.

Sowers, J. E., Stockland, W. L. \& Meade, R. J. (1972). J. Anim. Sci. 35, 782. 
Stockland, W. L., Meade, R. J., Wass, D. F. \& Sowers, J. E. (1973). J. Anim. Sci. 36, 526.

Williams, H. H., Curtin, L. V., Abraham, J., Loosli, J. K. \& Maynard, L. A. (1954). J. biol. Chem. 208, 277.

Womack, M. (1969). Proc. Soc. exp. Biol. Med. r3I, 977.

Womack, M. \& Rose, W. C. (194I). J. biol. Chem. r4I, 375.

Wootton, I. D. W. (1974). Micro-analysis in Medical Biochemistry, 5th ed. London: J. \& A. Churchill. 